2011

\title{
Book Review: The Role of Religion in 21st- Century Public Schools
}

Amy Lynn Dee

George Fox University, adee@georgefox.edu

Follow this and additional works at: https://digitalcommons.georgefox.edu/soe_faculty

Part of the Education Commons, and the Religion Commons

\section{Recommended Citation}

Dee, Amy Lynn, "Book Review: The Role of Religion in 21st-Century Public Schools" (2011). Faculty Publications - School of Education. 202.

https://digitalcommons.georgefox.edu/soe_faculty/202 


\title{
Steven P. Jones and Eric C. Sheffield (eds.)
}

\section{The Role of Religion in 21st-Century Public Schools}

\author{
New York: Peter Lang 2009 pb 227pp \$32.95
}

ISBN: 9781433107641

Jones and Sheffield have collected essays that speak to a broad range of interests surrounding the topic of religion in public schools. From Jones's commentary on the emotional underpinnings and historical context of the role of God in classrooms of children, to an account of the limitations of the establishment clause, and past a couple of reports on prayer in schools, the work takes readers through a course of chapters that touch upon many of the themes most popular in arguments about religion in school. Twelve unique chapters written by a diverse group of scholars grant the collection a plurality of perspectives that often eludes books centering on the most personal part of our existence that structures our view of all we hold sacred. Clearly, arguments in favor of or opposed to the inclusion of religion in our educational system involve passion not often matched in other debates, but Jones and Sheffield have amassed and presented work that represents mostly solid thinking on the role of religion in our schools.

At first glance, the reader might wonder about the organization and content of the essays contained within the volume. Upon further inspection, the tie between and the arrangement of the chapters become more than just the broad topic of religion in schools. Jones begins his chapter with an examination of what parents want for their children in school, and contrasts the views of Christian and non-Christian parents, sometimes succumbing to stereotyping to make his points. Jones grounds his account in the ancient question about whether one needs God in order to lead a "good" life and uses this as a guiding theme for presenting philosophical viewpoints on religion in school. Ultimately, says Jones, our understanding of the role of education in schools will allow for continued and thoughtful discourse on the topic.

Following Jones, the reader finds chapters by Nel Noddings, Jordan Lorence, T. Jeremy Gunn, and Steve Broidy that either follow Jones's philosophical approach or provide the legal foundation for reasoning about religion in schools. Noddings has given better, but her point about educating young people for intelligent unbelief supports the educational imperative that we work to give all students the ability to think critically about issues of faith. Lorence presents the point, missed by Noddings, that young students must understand that permitting viewpoints on religion does not constitute government endorsement; exclusion of faith actually impresses upon them the idea that the religious has no place in the secular world. Gunn and Broidy examine curriculum, albeit from different perspectives, but both lend important chapters to the collection.

The second group of essays center upon constitutional decisions and how the interpretations of those cases impact our system of education. Daniel Cohen, Susan E. Waters, and Craig A. Smith submit accounts about religious discrimination and prayer. Cohen writes about a Christian fraternity at the University of Missouri-Columbia and the ramifications such organizations have for the separation of church and state, not to mention the difficulty in sorting out the legal status of exclusive associations on public campuses. Waters and Smith tackle the neverending issue of prayer in public school. Both authors offer historical and legal accounts as well as including the public response to legislation. Those who have 
an interest in or questions about the legal aspects of school prayer will find both chapters accessible and informative.

Finally, the remaining chapters bring the reader back to a philosophical point of view, but this time with a tie to curriculum. Ryan Kennedy, the only secondary teacher among the contributors, gives the reader a personal glimpse of his attempts to integrate literature containing religious themes into his courses and what he learns from his teaching. Craig S. Engelhardt provides an excellent chapter on the role and importance of religion on the civic development of our students. He presents two proposals that provide readers with additional perspectives on religion in schools. Engelhardt suggests that public schools serve as a place for character development through the integration of moral beliefs into civic responsibility. Further, Engelhardt also asks readers to reconsider the role of religion in public education and the actual concept of public education so that the interrelationship between the religious and the civic unite with greater ease.

Andrew McKnight, Karla J. Smart-Morstad, and David P. Morstad Jr. close the book with chapters on teaching students with inflexible belief systems and on working with culturally and religiously pluralistic student populations. Both chapters offer the reader issues and questions to ponder as educators work within the constraints in place within a pluralistic society and a school system bound by the legislation of separation.

Given such a deeply emotional topic, Jones and Sheffield have offered a collection of essays worthy of commendation. Chapters are largely unbiased and informative, but they also present readers with fodder for additional conversations around a topic some might consider done, or tired at minimum. The book would serve as a wonderful addition to a course on religion in public schools, or as a supplement to any administrative licensure program where candidates want a comprehensive collection of views on the role of religion in schools. 